\title{
Use of abbreviations in the nursing records of a teaching hospital
}

\author{
Uso de abreviaturas nos registros de enfermagem em um hospital de ensino
}

Sylvia Miranda Carneiro ${ }^{1}$, Herica Silva Dutra ${ }^{1}$, Fernanda Mazzoni da Costa $^{1}$, Simone Emerich Mendes ${ }^{1}$, Cristina Arreguy-Sena ${ }^{1}$

Objective: to evaluate the use of abbreviations in nursing records of a teaching hospital and describe their profile in different sectors, work shifts and professional nursing categories. Methods: documentary study that analyzed 627 nursing records in 24 patient charts using a systematic observation script. Results: we identified 1,792 abbreviations, and 35.8\% were nonstandard. The incidence of abbreviations was higher in the Intensive Care Unit, used by nurses and in the night shift. Conclusion: abbreviations are part of the day-to-day of nursing records. The use of nonstandard abbreviations make difficult to understand the records content, can generate misinterpretations, put at risk the users' safety and impair the continuity of labor work.

Descriptors: Nursing Records; Abbreviations; Health Communication; Nursing, Team.

Objetivo: avaliar a utilização de abreviaturas nos registros de enfermagem de um hospital de ensino descrevendo seu perfil nos diferentes setores, turnos de trabalho e categorias profissionais de enfermagem. Métodos: estudo documental analisou 627 registros de enfermagem em 24 prontuários utilizando um roteiro de observação sistematizado. Resultados: foram identificadas 1.792 abreviaturas, sendo 35,8\% não padronizadas. A incidência de abreviaturas foi maior na Unidade de Terapia Intensiva, utilizadas pelos enfermeiros e no período noturno. Conclusão: abreviaturas fazem parte do cotidiano dos registros de enfermagem. 0 uso de abreviaturas não padronizadas dificulta a compreensão do conteúdo do registro e pode gerar interpretações equivocadas e colocar em risco a segurança do usuário, além de comprometer a continuidade do trabalho laboral.

Descritores: Registros de Enfermagem; Abreviaturas; Comunicação em Saúde; Equipe de Enfermagem.

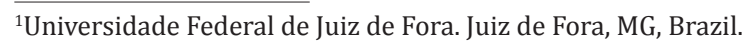




\section{Introduction}

One of the requirements for quality care is effective communication in order to promote conditions that help professionals to prevent errors, allowing messages to be transmitted and received in a clear, correct and safe manner ${ }^{(1-2)}$.

Nursing records are a constituent part of the health information system and should be performed in order to provide information about the general state of the patient, improve the communication between the nursing team and the multidisciplinary team, ensure continuity of care in 24 hours, portray the care provided, legally endorse the work of the professional, promote continuity of $\operatorname{care}^{(1-3)}$, as a tool for audits ${ }^{(4)}$ and scientific research source, and contribute as information database in conducting research and teaching.

The development of the nursing record is part of the legal duties of the profession, which provides that its realization is responsibility of all team members. The nursing record should convey inherent and indispensable information to the care process and be performed in the patient chart and in other nursing documents $^{(5)}$.

Regardless of where nursing care is performed, it needs to be systematized by a scientific methodology and professionals should held a record of summary information regarding the nursing problem, the planned therapeutic procedures and the results presented by the individual ${ }^{(1,3,6)}$.

To obtain the continuity of records, nurses have the responsibility to encourage that the documentation process is continuous, clear, objective and complete, and nursing professionals have the duty to provide complete and reliable written and verbal information, necessary to ensure continuity of nursing care, free of damage from malpractice, negligence or recklessness ${ }^{(5)}$.

In clinical practice, nursing records often contain abbreviations and/or acronyms. The acronyms are considered a type of abbreviation made with the letters or initial syllables of words that constitute them ${ }^{(2,7)}$. In this study, the terminology of abbreviations was adopted to express expressions by meeting syllables and/or letters in order to streamline the communication process.

From the communication point of view, the use of abbreviations has as assumptions: the communication as a procedural and complex activity that uses the symbolic interaction to give meaning to received and sent messages, using signs, whose content needs to be shared in their meanings between sender and receiver so that there is a reduction of communication noises and so that information graphically recorded in the records and official documents of the patient can express actions performed in an organizational context $^{(8-9)}$.

When known, standardized, contextualized and properly used, abbreviations can successfully integrate the communication vocabulary of the nursing staff ${ }^{(2)}$ in hospitals and optimize work processes characterized by the growing demand from patients and activities in health services, which requires a fast pace to perform and record the daily activities of these professionals ${ }^{(1)}$. On the other hand, when incorrectly used or out of context, they may generate communication noise, increasing the risk of iatrogenesis ${ }^{(2,7,10-11)}$, favoring reading and interpretation mistakes, and increasing the work of those who try to understand them ${ }^{(11)}$.

The use of abbreviations has been designed as part of the communication process made possible through nursing records that transmit information about users and their treatment for themselves, their family, the institution and the scientific community ${ }^{(1,6)}$.

Abbreviations integrate a literary style used in nursing records whose characteristics are: descriptive, documentary, containing information and using symbols $^{(11)}$. The content of the information recorded is about the health status, labor actions/decisions and their results, how the professional practice occurred to give technical, legal, scientific and humanistic support to the care process conducted ${ }^{(1,11)}$.

The only abbreviations accepted worldwide 
with established definitions are the units of measurement established by the International System of Units, based on the units of length, mass, time, electric current, temperature, thermodynamics, amount of substance and luminous intensity ${ }^{(12)}$. In Brazil, the International System of Units was officially adopted by Resolution No. 12 of 1988, of the National Council of Metrology, Standardization and Industrial Quality, as a form of standardization ${ }^{(13)}$.

It is worth mentioning that, in the places where nursing actions are performed, there should be conduction of records, and health institutions have the authority to set their documentation requirements on the actions and corroborating content of the nursing performances, provided that they are included in the nursing services organization manual ${ }^{(14)}$.

Given the above, authors adopted as research object the use of abbreviations in nursing records of a hospital.

The reasons for its study are grounded in the importance of discussing the use of abbreviations in nursing records from the following parameters: 1) the use of acronyms/abbreviations should be avoided to the maximum in the documentary records when nonstandardized in the institution $\left.{ }^{(2,10)} ; 2\right)$ the presence of correct, organized, secure, complete and available information and standard abbreviations reduce noise in communication, minimize failures in the labor process, reduce the risk to patients treated ${ }^{(1,7)}$, favor the documentation of professional actions and health status of the patient; 3) when properly used, they can prevent damage and speed up the work process ${ }^{(2,11)}$; 4) the correct institutional documentation supports financing and reimbursement by insurance institutions $^{(4)}$; and, 5) continuous and updated records qualify the care and promote the empowerment of nursing professionals, and ward off allegations of incompetence, recklessness or negligence in the care provided $^{(5)}$.

Thus, the study aimed to evaluate the use of abbreviations in nursing records of a teaching hospital and describe the profile in different sectors, work shifts and professional categories of the nursing staff.

\section{Methods}

Documentary research, on abbreviations used in the records made by the nursing staff on charts of people admitted to a teaching hospital of the Zona da Mata Mineira Region. This hospital has an installed and occupational capacity of 140 beds and is a reference in the Unified Health System network in Minas Gerais, southeastern Brazil.

Sample by typicality should be used in situations where various issues prevent the use of probability sample. In this case, the researcher must seek alternative ways to obtain a representative sample ${ }^{(15)}$. Authors adopted this type of sample due to the period of implementation of the standardization of abbreviations in the institution, a fact that prevented the inclusion of previous records to February 2013. Therefore, the inclusion criteria were established in order to obtain a profile of the use of abbreviations that addressed the records of nursing professionals of all categories (nurses, nursing technicians and nursing assistants), of different sectors of the institution, in day and night shifts.

Data were collected from 627 records of archived charts in the hospital's Medical Records and Statistics Service, in the period from March to May 2013.

Inclusion criteria were the records of charts: 1) of people hospitalized in Medical Clinic, Surgery unit, Intensive Care Unit and Pediatric unit with minimum stay of 10 days/hospitalization; 2) records of all nursing categories (nurses, nursing technicians and nursing assistants). Records without identification of the professional category, but who had the professional registration number of the Minas Gerais Regional Nursing Council recorded manually or those made on a paper for the exclusive use of nursing professionals were also included. Exclusion criteria were: records conducted by academics. A total of 24 charts were analyzed, four from each sector. Only one 
record of each abbreviation described in the chart was considered for analysis.

Data collection was made from a systemized observation script previously prepared. The criteria used in reading the records were: readability and clarity of information; identification of the professional in charge and their registration number in the professional council ${ }^{(14)}$ (inserted by stamp or manually) to the final record; and the presence of institutionally standardized abbreviations ${ }^{(2)}$.

Criteria used for analysis of abbreviations were: institutional standardization, which derives from work instruction for nursing records $s^{(16)}$, record out of context (use by the issuer of linguistic elements in the production of nursing records that allow their understanding by the recipient within the communication situation in which it is inserted, that is, nursing care in hospital), readability, textual relevance (use of concepts that allow the construction of a logical sense to the nursing record), and comprehensiveness (the abbreviations whose meaning could not be understood were categorized as non-identified and those that are not part of the institutional standardization list were categorized as nonstandard).

The abbreviations standardizing list of that institution was developed from literature searches and public data from other institutions agreed by the institutional standardization team. Abbreviations used in the daily life by nursing professionals at the time of its preparation were not considered. The list is divided into seven related classes: patient assessment, professional category/titration, the patient's clinical conditions, procedures, medications, external bodies and sectors of the institution, and units of measurement and chemicals.

Then, researchers conducted the content analysis ${ }^{(17)}$, in order to provide documentation (explain, systematize and provide understanding) of the contents of abbreviations from the pre-analysis (selection of records), material explanation (coding of abbreviations) and processing of the results (interpretation from statistical analysis).

The review process was carried out by reading the contents of the records, identifying the abbreviations' meanings and comparing with the institutional abbreviations standardization list in order to identify their meaning and standardization.

Data were consolidated in the Statistical Package for Social Sciences version 21.0 and analyzed by descriptive and inferential statistics (chi-square test, for $\mathrm{p}$-value $\leq 0.05$ ). The chi-square test was used to identify statistically significant differences between occupational categories, sectors of the institution and work shifts regarding the use of standardization and identification of abbreviations.

The study complied with the formal requirements contained in the national and international regulatory standards of research involving human subjects.

\section{Results}

Of the 24 charts containing 627 nursing records, authors were able to identify 1,792 abbreviations. The sector with greater use of abbreviations in number and standardizing was the Intensive Care Unit. There were $35.0 \%$ of records without identification of the professional category.

The profile characteristics of abbreviations and acronyms are contained in Table 1.

The fact that the researched institution has the standardization of abbreviations in seven classes (16) made it possible to identify them by: patient assessment 817 (45.6\%); professional category/ titration 13 (0.7\%); patient's clinical condition 130 (7.3\%); procedures 560 (31.3\%); medicines 113 (6.3\%); external bodies and sectors of the institution $9(0.5 \%)$ and units of measurement and chemical elements 101 (5.6\%), totaling 1743 (97.3\%) of the abbreviations analyzed. 
Table 1 - Profile of abbreviations by sector professional category and shift

\begin{tabular}{lc}
\hline Variables & $\mathbf{n}(\mathbf{\%})$ \\
\hline Sector & \\
Intensive Care Unit & $1013(56,5)$ \\
Male Medical Clinic & $85(4,8)$ \\
Female Medical Clinic & $32(1,8)$ \\
Pediatrics & $126(7,0)$ \\
Male Surgery & $217(12,1)$ \\
Female Surgery & $319(17,8)$ \\
Category & \\
Nurse & $704(39,3)$ \\
Nursing Technician & $412(23,0)$ \\
Nursing Assistant & $48(2,7)$ \\
Category unidentified & $628(35,0)$ \\
Shift & $1792(100,0)$ \\
Day & $679(37,9)$ \\
Night & \\
Total & \\
\hline
\end{tabular}

The fact that some abbreviations prevented their classification among the above categories meant that, even after reading their context in the records, authors could not understand them. Thus, in addition to evaluating the standardization, the comprehensiveness of abbreviations was also evaluated, taking into consideration whether the context of the record provided any understanding of the meaning thereof. In this sense, those who could be understood were classified as identified; and those whose meaning was not understood were classified as unidentified. It is worth mentioning it was impossible to identify $49(2.7 \%)$ of them, as they were not included in the institution's standardization list.

For analysis purposes, the standardization of abbreviations in seven classes was regrouped into three areas: abbreviations related to the patient (patient assessment and clinical conditions), abbreviations related to care and procedures performed by nursing staff (professional category and procedures) and abbreviations related to other aspects (medicines, external bodies and sectors and units of measurements and chemicals), and 35.8\% were not standardized by the institution. Abbreviations found in the records were also evaluated regarding institutional standardization, that is, whether or not they appeared in the standardization list available in the institution (Table 2).

Table 2 - Classification of abbreviations and standardization

\begin{tabular}{lccc}
\hline \multirow{2}{*}{$\begin{array}{l}\text { Abbreviation related to: } \\
\mathbf{( p = 0 . 0 4 5 ) *}\end{array}$} & $\begin{array}{c}\text { Yes } \\
\mathbf{n}(\%)\end{array}$ & $\begin{array}{c}\text { No } \\
\mathbf{n}(\%)\end{array}$ & $\begin{array}{c}\text { Total } \\
\mathbf{n}(\%)\end{array}$ \\
\cline { 2 - 4 } & $685(72.3)$ & $262(27.7)$ & $947(100.0)$ \\
Pacient & $352(52.3)$ & $321(47.7)$ & $673(100.0)$ \\
$\begin{array}{l}\text { Care and procedures performed } \\
\text { by the Nursing Team }\end{array}$ & $113(91.9)$ & $10(8.1)$ & $123(100.0)$ \\
$\begin{array}{l}\text { Other aspects } \\
\begin{array}{l}\text { Abbreviations not identified in } \\
\text { the context of nursing records }\end{array}\end{array}$ & - & $49(100.0)$ & $49(100.0)$ \\
$\begin{array}{l}\text { Total } \\
\text { *Chi-square test }\end{array}$ & $1150(64.2)$ & $642(35.8)$ & $1792(100.0)$ \\
\hline
\end{tabular}

The standardization and identification of abbreviations according to professional categories, sectors and shifts appear in the Tables 3, 4 and 5.

Table 3 - Standardization and identification of abbreviations by professional category

\begin{tabular}{|c|c|c|c|c|c|}
\hline \multirow{3}{*}{ Categories } & \multicolumn{2}{|c|}{$\begin{array}{c}\text { Standard } \\
\text { abbreviation } \\
(\mathrm{p}<0.001 *)\end{array}$} & \multicolumn{2}{|c|}{$\begin{array}{c}\text { Identified } \\
\text { abbreviation } \\
\left(p=0.145^{*}\right)\end{array}$} & \multirow{3}{*}{$\begin{array}{l}\text { Total } \\
\text { n (\%) }\end{array}$} \\
\hline & Yes & No & Yes & No & \\
\hline & n (\%) & n (\%) & n (\%) & n (\%) & \\
\hline
\end{tabular}

Nursing Technician 254(61.8) 157(38.2) 394(95.9) 17(4.1) 411(100.0)

$\begin{array}{lllll}\text { Nursing Assistant } \quad 22(45.8) & 26(54.2) & 47(97.9) & 1(2.1) & 48(100.0)\end{array}$ Not identified $\quad 372(59.2) 256(40.8) 617(98.2) 11(1.8) 628(100.0)$

*Chi-square test 
Table 4 - Standardization and identification of abbreviations by sector

\begin{tabular}{cccccc}
\hline \multirow{2}{*}{ Sectors } & \multicolumn{2}{c}{$\begin{array}{c}\text { Standard } \\
\text { abbreviation } \\
\left(\mathbf{p}=0.092^{*}\right)\end{array}$} & \multicolumn{2}{c}{$\begin{array}{c}\text { Identified } \\
\text { abbreviation } \\
(\mathbf{p}=0.129 *)\end{array}$} & Total \\
\cline { 2 - 4 } & Yes & No & Yes & No & \\
& $\mathbf{n}(\%)$ & $\mathbf{n}(\%)$ & $\mathbf{n}(\%)$ & $\mathbf{n}(\%)$ & $\mathbf{n}(\%)$ \\
\hline
\end{tabular}

Intensive Care Unit 680(67.1) 333(32.9) 993(98.0) 20(2.0) 1013(100.0)

$\begin{array}{lllll}\text { Male clinic } \quad 53(62.4) & 32(37.6) & 82(96.5) & 3(3.5) & 85(100.0)\end{array}$

$\begin{array}{lllll}\text { Female clinic } \quad 20(62.5) & 12(37.5) & 32(100.0) \quad-\quad 32(100.0)\end{array}$

$\begin{array}{llllll}\text { Pediatrics } & 78(61.9) & 48(38.1) & 119(94.4) & 7(5.6) & 126(100.0)\end{array}$

$\begin{array}{llllll}\text { Male surgery } \quad 131(60.4) & 86(39.6) & 210(96.8) & 7(3.2) & 217(100.0)\end{array}$

$\begin{array}{llllll}\text { Female surgery } \quad 188(58.9) & 131(41.1) & 307(96.2) & 12(3.8) & 319(100.0)\end{array}$

*Chi-square test

Table 5 - Standardization and identification of abbreviations by shift

\begin{tabular}{cccccc}
\hline \multirow{2}{*}{ Shifts } & \multicolumn{2}{c}{$\begin{array}{c}\text { Standard } \\
\text { abbreviation } \\
(\mathbf{p}=\mathbf{0 . 4 5 5})\end{array}$} & \multicolumn{2}{c}{$\begin{array}{c}\text { Identified } \\
\text { abbreviation } \\
(\mathbf{p}=\mathbf{0 . 1 1 1})\end{array}$} & \multirow{2}{*}{ Total } \\
\cline { 2 - 4 } & Yes & No & Yes & No & \\
\cline { 5 - 6 } & $\mathbf{n}(\%)$ & $\mathbf{n}(\%)$ & $\mathbf{n}(\%)$ & $\mathbf{n}(\%)$ & n (\%) \\
\hline
\end{tabular}

Day $434(63.9) 245(36.1) \quad 665(97.9) \quad 14(2.1) \quad 679(100.0)$

Night 716 (64.3) 397 (35.7) 1078 (96.9) 35 (3.1) 1113 (100.0) *Chi-square test

There was a statistically significant difference ( $p<0.001$ ) only between the professional categories for the use of standard abbreviations. The highest proportion of standard abbreviations was used by nurses $(71.2 \%)$ and the highest proportion of nonstandard abbreviations was used by nursing assistants (54.2\%).

Among the non-official nomenclatures, researchers identified the use of: IH meaning intravenous hydration, cited 63 times; ETT (endotracheal tube), 52 times; PVA (peripheral venous access), 51 times; and NEP (nasoenteric probe), with 43 uses, among others. It is noteworthy the high frequency of use of non-standard abbreviations such as "Pct" (patient), with 32 uses.

\section{Discussion}

The Intensive Care Unit was the sector with the highest number of abbreviations. This fact can be explained by the existence of: hemodynamic instability of the patient; limited time to perform the professional records; peculiarity of the labor process in the sector; profile of the clientele seen in a closed sector whose Systematization of Nursing Care was pilot, implemented since $2000^{(6)}$.

Abbreviations commonly used were identified in Intensive Care, as IH (intravenous hydration), ETT (endotracheal tube) and NEP (nasoenteric probe), which were not standardized in the institution. On the other hand, there were in the institutional standardization list $^{(16)}$ abbreviations with similar meanings, such as NGC (nasogastric catheter), IV (intravenous) and OTI (orotracheal intubation). As pointed out earlier, the institutional standardization list was developed from bibliographic references, disregarding the reality of use of abbreviations in the institution. This may explain this finding and the fact that abbreviations commonly used in the literature were not included in the list in force during the period of the study.

It is worth mentioning that the fact that other units have not consolidated the Systematization of Nursing Care may explain the lower number of records.

The professionals of the night shift made $24.2 \%$ more abbreviations when compared to those of the day shift, and made greater use of standardized abbreviations, evidence corroborated by another study in which the use of standardized abbreviations was higher among professionals in the night shift(18). The distribution of duties according to the shift justifies that exams, professional, distribution of diets, surgeries and referrals are less frequent at night, which allows more time to perform the records.

From the standpoint of the daily care available 
to people admitted, it can be inferred about how the care activities performed by the nursing team have a continuous documentary character, whose content treats of the institutional care provided and the client/professional relationship, centered in care ${ }^{(1,3,19)}$. In this context, the use of abbreviation appears to be feasible and useful inasmuch as it combines time/ registration/documentation and portrays quality criteria in the care provided.

The percentage of nonstandard abbreviations identified in the records made in the medical charts was $35.8 \%$, a fact identified in other realities, whose number ranged from $5.7 \%{ }^{(18)}$ to $83.0 \%$ of $\operatorname{cases}^{(20)}$.

There is evidence that support the importance of standardization of abbreviations in health institutions and that warn that those not standardized can cause communication noises, negatively influence the continuity of nursing care and impair its functionality and usefulness as a communication and effectiveness tool of the quality of care ${ }^{(19)}$.

Abbreviations, as communicational component that enables the nursing records used in the daily clinical practice of the nursing staff, portray a literary style that uses technical terms and scientific writing ${ }^{(11)}$ whose content treats of health conditions, therapeutic procedures, the conduction of the treatment and the actual and potential responses ${ }^{(1)}$, moments of life and illness of users in a morbidity period and/or institutional hospitalization.

Its use modulates the purpose, the meaning, the scope and the consequences of therapeutic procedures, and the use of abbreviations in place or synonymous to scientific language may generate language vices and repetition of acronyms that, although may be routinely used, are undesirable from the standpoint of the scientific community and the communication risk that may trigger ${ }^{(11)}$.

When comparing the percentage of use of standardized abbreviations in the professional categories, it was identified that nurses use them more $(71.2 \%)$ when compared to nursing assistants (45.8\%).
The reason for this difference may be linked to the fact that: technical and nursing assistants are trained in middle or elementary level, while nurses have higher level of education, which provides opportunities to use scientific and technical language from the earliest periods of their education and; nurses, for their concern with management functions and continuing education, are more attentive to the use of the list of standard abbreviations that was available at the institution in all sectors ${ }^{(21)}$. This may also explain the higher percentage of incomprehensible abbreviations used by nursing technicians (4.1\%).

There is evidence that show that the guidance, supervision, the professional commitment of nurses in leading their team, the permanent education service and the in-service training are strategies that may improve the records held by the nursing team ${ }^{(3)}$.

Although all sectors have used nonstandard abbreviations, there is highlight for the female and male surgical clinic ( $41.1 \%$ and $39.6 \%$, respectively), in contrast to the Intensive Care Unit, which, despite the large number of abbreviations, was the sector that less used nonstandard abbreviations (32.9\%).

The fact that the institution's abbreviations standardized list has been drawn from literature searches and public data from other institutions and do not contemplate abbreviations used in the routine of their nursing professionals can justify the presence of the quantity of nonstandard abbreviations in the evaluated records.

\section{Conclusion}

Abbreviations are part of the day-today of the nursing records of the institution studied, and the use of institutional standardization is more frequent in the Intensive Care Unit, the night shift and among nurses.

The use of nonstandard abbreviations, however, should be avoided, given that their misuse can cause communication noise, difficulty to understand the contents of the note and can generate misinterpretations, even endangering the safety of the 
user and compromise the continuity of work.

The contribution of the present research lies in the fact that it bring material for reflection on the quality of the records regarding the use of abbreviations, so that they are informative about the health condition of users, written in a clear and objective manner and complete, to serve as a tool for audits and scientific research and to support the professional practice.

As limitations of this research there is the fact that it was conducted at a single institution, only analyzed the records of nursing professionals and was directed to the exclusive study of abbreviations. Studies involving broader aspects related to nursing records, involving records of all health team professionals and academics should be conducted in order to provide a broader view about the patient chart records and the importance of multi-professional communication in search for a comprehensive care.

Given the information obtained, it is suggested the implementation of guidance strategies and systematic training of professionals to make them aware of the importance of correctness and clarity of nursing records and to introduce computerization with the inclusion of autofill tools that reduce the use of nonstandard abbreviations.

\section{Acknowledgements}

To the Coordination of Higher Education Personnel Improvement (Process № 23038.002221/201402) (Dutra HS and Costa FC); to the Federal University of Juiz de Fora, Institutional Scholarship Program for Scientific Initiation (Mendes SE) and for Professional Training (Carneiro MC); and to the professionals of the University Hospital of the Federal University of Juiz de Fora, who contributed to this research.

\section{Collaborations}

Carneiro SM, Dutra HS, Coast FM and Arreguy -Sena C contributed to the design, analysis, data interpretation, article writing, relevant critical review and approval of the final version to be published. Mendes SE contributed to the design, analysis, data interpretation and writing of the article.

\section{References}

1. Blair W, Smith B. Nursing documentation: frameworks and barriers. Contemp Nurse. 2012; 41(2):160-8.

2. Royal College of Nursing. Abbreviations and other short forms in patient/clinic records. United Kingdon: RCN; 2012.

3. Wang N, Hailey D, Yu P. Quality of nursing documentation and approaches to its evaluation: a mixed-method systematic review. J Adv Nurs. 2011; 67(9):1858-75.

4. Claudino HG, Gouveia EML, Santos SR, Lopes MEL. Auditoria em registros de enfermagem: revisão integrativa da literatura. Rev Enferm UERJ. 2013; 21(3):397-402.

5. Conselho Federal de Enfermagem. Resolução COFEN 311, de 08 de fevereiro de 2007. Aprova a reformulação do código de ética dos profissionais de enfermagem [Internet]. 2007 [citado 2015 set 10]. Disponível em: http://www.cofen.gov.br/ resoluo-cofen-3112007_4345.html

6. Conselho Federal de Enfermagem. Resolução COFEN-358/2009. Dispõe sobre a Sistematização da Assistência de Enfermagem e a implementação do Processo de Enfermagem em ambientes, públicos ou privados, em que ocorre o cuidado profissional de Enfermagem, e dá outras providências. [Internet]. 2009 [citado 2015 set 10]. Disponível em: http://www.cofen.gov.br/ resoluo-cofen-3582009_4384.html 
7. Lövestam E, Velupillai S, Kvist M. Abbreviations in swedish clinical text-use by three professions. Stud Health Technol Inform. 2013; 205:720-4.

8. Ferreira GM, Hohlfeldt A, Martino LC, Morais OJ. Teorias da comunicação: trajetórias investigativas. Porto Alegre: EDIPUCRS; 2010.

9. França VV, Aldé A, Ramos MC, organizadores. Teorias da comunicação no Brasil: reflexões contemporâneas. Salvador: EDUFBA; 2014.

10. Rees G. Staff use of acronyms in electronic care records. Ment Health Pract. 2013; 16(10):28-31.

11. Mansur AJ. Abreviaturas. Diagn Tratamento. 2011; 16(3):121-2.

12. Instituto Nacional de Metrologia, Qualidade e Tecnologia (INMETRO). Sistema Internacional de Unidades: SI. Duque de Caxias, RJ: INMETRO/ CICMA/SEPIN; 2012.

13. Conselho Nacional de Metrologia, Normalização e Qualidade Industrial - CONMETRO. Resolução no 11, de 12 de outubro de 1988 [Internet]. 1988 [citado 2015 ago 31]. Disponível em: http://www. inmetro.gov.br/resc/pdf/RESC000114.pdf

14. Conselho Regional de Enfermagem-MG. Deliberação COREN-MG no 135 de 10 de outubro de 2000. Normatiza no Estado de Minas Gerais os princípios gerais para ações que constituem a documentação da Enfermagem. [Internet]. 2000 [citado 2015 set 08]. Disponível em: http://sig. corenmg.gov.br/sistemas/file/doc/legislacoes / docs/doc_legis_7.pdf
15. Marconi MA, Lakatos EM. Técnicas de pesquisa. São Paulo: Atlas; 2008.

16. Hospital Universitário da Universidade Federal de Juiz de Fora. Elaboração dos registros de enfermagem: instrução de trabalho. Juiz de Fora, 2012 .

17. Bardin L. Análise de Conteúdo. São Paulo: Edições $70 ; 2011$.

18. Rosa LA, Caetano LA, Matos SS, Reis DC. Auditoria como estratégia de avaliação dos registros de enfermagem em unidade de internação pediátrica. Rev Min Enferm. 2012; 16(4):553-46.

19. Jefferies D. Communicate with clarity: correct use of abbreviations and phrases in nursing records is vital for care efficiency and safety, writes Diana Jefferies. Nurs Stand. 2012; 26(40):62-3.

20. Apolinario LA, Vieira MR. Avaliação dos registros de enfermagem em unidades pediátricas de um hospital de ensino. Arq Ciênc Saúde. 2012; 19(1):9-13.

21. Lima EC, Appolinário RS. A educação profissionalizante em enfermagem no Brasil: desafios e perspectivas. Rev Enferm UERJ. 2011; 19(2):311-6. 